Original Research Paper

\title{
Factor Affecting Technical Efficiency of Smallholder Rubber Farming in Northeast Thailand
}

\author{
${ }^{1}$ Poungchompu, S. and ${ }^{2}$ S. Chantanop \\ ${ }^{I}$ Department of Agricultural Economics, \\ Faculty of Agriculture, KhonKaen University, KhonKaen, 40002, Thailand \\ ${ }^{2}$ Department of Economics, Faculty of Economics, \\ Northeastern University, KhonKaen, 40000, Thailand
}

\author{
Article history \\ Received: 18-05-2015 \\ Revised: 26-05-2015 \\ Accepted: 18-6-2015 \\ Corresponding Author: \\ Poungchompu, S. \\ Department of Agricultural \\ Economics, Faculty of \\ Agriculture, KhonKaen \\ University, KhonKaen, 40002, \\ Thailand \\ Email: psuppap@kku.ac.th
}

\begin{abstract}
With the increase of rubber production, Para rubber farmers in Northeastern Thailand have faced the limited physical and socio-economic conditions that have given rise to the improvement of technical efficiency. This study investigated the technical efficiency of Para rubber farmers. A multi-stage random sampling technique was used to collect cross sectional data on 300 farmers. The data was analyzed using descriptive statistics and stochastic frontier analysis. The results revealed that the variance of gamma and sigma squared of the frontier production function was significant at a level of $p=0.01$. All inputs (except chemical fertilizer) are major factors that have influenced the changes in the output of Para rubber production. The mean technical efficiency index for the farmers was found to be 0.573 and the efficiency factors, which were comprised of age of farmers, education, gender and age of the rubber trees, were found to be the significant factors that affected the variation in technical efficiency among the farmers. The policy implication of the study is that technical efficiency of Para rubber could be increased by $42.7 \%$ by improving the use of available resources. Thus, the government should give more education about rubber production, including tapping trees and managing farms because this education will impact the knowledge that can be applied to farming techniques in order to enhance efficiency.
\end{abstract}

Keywords: Para Rubber, Stochastic Frontier, Productivity, Technical Efficiency

\section{Introduction}

Para rubber is an economic crop of Thailand. In the last decade, Thailand has become the largest natural rubber producer and exporter in the world. The original rubber plantations of Thailand were located in the South and the East, owing to the suitable environment for rubber cultivation. Later, the government created a policy to expand rubber as a new cash crop in order to raise income and stabilize the small landholders in the new planting areas both in the Northeast and in the North (approximately 160,000 ha between the years of 2004 to 2006). Para rubber has become the main economic plant of the Northeast since then. In 2011, the Ministry of Agriculture \& Cooperatives was pushing the project of rubber plantations in new land (Phase 3: Year 20112013) by co-integrating with a subsidiary organization to build up sustention for all rubber farmers of the nation (The Thai Rubber Association, 2013). The launch of Para rubber projects in Northeastern Thailand has given rise to increased rubber growing areas ranging from about 240,000 hectares in 2009 , or $9.5 \%$ of the agricultural area, to 18.3 million hectares in 2010 . The tapping area covered 932,679 acres in 2010, which produced 230,504 tons, or $247 \mathrm{~kg}$ per acre $(7.6 \%$ of national production). According to the Bank of Thailand's Northeastern office, in 2011 the average cultivated area had increased to $24.2 \%$ per year over the past 10 years (from 2000 to 2010). As a result, this area represents the second largest cultivated area in the region of Thailand. In addition, in 2010 the average production in the Northeast was about 1.56 ton/ha/year. When all provinces in the Northeastern were compared, it was found that NongKhai province had the most tapping 
areas (approximately 36,272 ha) and the gain of the output was 52,115 tons. Following NongKhai were Burirum (14,319 ha with total production of about 22,910 tons) and UdonThani $(11,646$ ha with total production of about 19,871 tons) (OAE, 2011).

Therefore, it can be predicted that rubber plant cultivation in Northeastern Thailand will become a more significant factor which will affect the whole country because the rubber sector will thrive by increasing the cultivated areas rather than by improving yield and technical efficiency. Nevertheless, the rubber plantations in this area are dominated by farmers with small holdings, many of which are less than two to three hectares. Moreover, despite that the Para rubber plantations have positively impacted the livelihoods of farmers via raising household income, Para rubber farmers face some difficulties related to the high production costs, including chemical fertilizers and hired labor. This has resulted in an increase on loan dependence from the Bank of Agriculture and Agricultural Cooperatives. Rahman and Takeda (2007) found that almost small farmers used credit to purchase chemical fertilizers. Also, seasonal fluctuations in pricing and quality affect the farmers' ability to obtain a stable income. Another problem is skilled labor employment. The tapping labor for rubber plantations came from two main sources, that is, the local labor that included the farmer's relatives and neighbors in the community and the external labor force, which includes foreign laborers who are not very skilled. Additionally, Para rubber growers in these areas are faced with limited physical conditions, such as a diminished soil fertility, high temperatures and low humidity which are unsuitable for rubber plantations (Laura, 2006), resulting in the necessity of improving technical efficiency. This is due to the fact that a newly planted area may face unpredictable weather that will lead to uncertain levels of production. It has been shown that unfavorable environmental conditions would more drastically affect the latex yield than the timber production of rubber (Grist et al., 1998). In areas where rubber cultivation is less favored by environmental conditions, improved farming systems and improved farming production could be an option to increase the economical profitability, as well as the environmental and social benefits of rubber cultivation. These aforementioned physical and socioeconomic factors have led to the technical inefficiency of production. As a result, the rubber yield in those areas is lower than other areas. That is, the average yield in the area is $248 \mathrm{~kg} / \mathrm{rai}$ ( 1 ha is $6.25 \mathrm{rai}$ ), compared to 262 $\mathrm{kg} / \mathrm{rai}$ for the whole country (OAE, 2011). Thus, farmers need to improve the efficiency and productivity levels. Thus, the specific objectives of this study were to estimate and examine the effects of the socio-economic status and physical factors of rubber farmers on their production efficiency. A study on technical efficiency of rubber is relevant to the present investigation of Hashim and Nik (2011). The mean technical efficiency of rubber farm in Malaysia is 0.81 of 35 farmers. The quantity of fertilizer application, husbandry practice, skill, motivation and experience of operators, management competence of the supervisors, soil fertility, species of the rubber trees and weather conditions are factors affecting productivity and technical efficiency. Also, the technical efficiency of state rubber farms in Vietnam from 33 farms has a mean TE of 0.59. The management and different field husbandry methods adopted in the farms have contributed to this difference (Tran et al., 1993). Moreover, there were substantial variations in estimated efficiencies ranging from 0.38 for the least practiced tapper and 0.99 for the best tapper with a mean technical efficiency of 0.72 . The technical inefficiency of rubber tapping in Nigeria revealed that education, training and gender were found to have significant effect on tappers efficiency (Giroh and Adebayo, 2009).

\section{Methodology}

\section{The Study Area}

The study was conducted in the following four major Para rubber areas in Northeastern Thailand (Fig. 1): the upper area, including NongKhai and UdonThan and lower area, including KhonKaen and Buriram provinces. NongKhai (17 $52^{\prime} 34^{\prime \prime}$ North, $102^{\circ} 44^{\prime} 40^{\prime \prime}$ East) is situated in the Northeastern part of Thailand about 615 $\mathrm{km}$ from Bangkok and is located on the right bank of the Mekhong River opposite to ThaDua of Laos. The total area is about 7,332,280 square kilometers, or 4,582,675 rai. The mountains and forest extend to Loei Province. The highest land is in the south and is approximately 1,200 feet above sea level (NongKhai, 2013). UdonThani (17 $17^{\prime} 51^{\prime \prime}$ North, 103 ${ }^{\circ} 9^{\prime} 9^{\prime \prime}$ East) is located on a plateau, which is approximately 187 meters above sea level. Most of the area is covered with rice fields, forests and hills (UdonThani, 2013). The Phu Pan Mountain Range and the Songkhram River are the province's two primary natural attractions. KhonKaen ( $16^{\circ} 26^{\prime} 20^{\prime \prime}$ North, $102^{\circ} 49^{\prime} 43^{\prime \prime}$ East) is the secondlargest of the Northeastern provinces of Thailand and is located in the heart of the Khorat Plateau with a total area of 10,886.0 square kilometers and covers an area of 11,424 square kilometers (equivalent to 7.14 million rai of land) (KhonKaen, 2013). Buriram (14 $59^{\prime} 39^{\prime \prime}$ North, $103^{\circ} 06^{\prime} 08^{\prime \prime}$ East) is at the south end of the Khorat Plateau, with several extinct volcanoes around the province and covers an area is 10,322.9 square kilometers (Buriram, 2013). The people of these four provinces are mostly farmers who grow rice, cassava, sugarcane and Para rubber. 


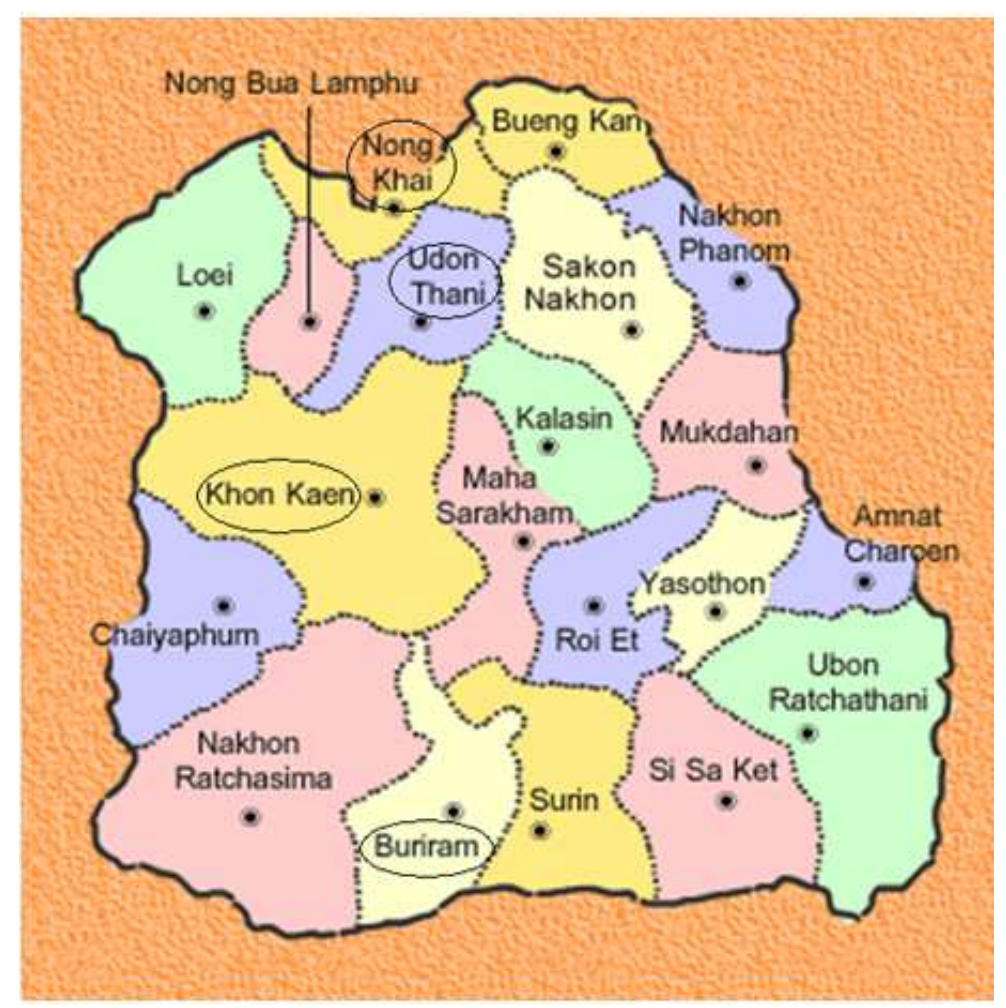

Fig. 1. Map of Isaan Thailand: Source: The Thailand life, 2015

The Para rubber cultivating area is about $128,496.8$ ha of the total cultivating area $(556,368.5$ ha) of Northeastern Thailand (OAE, 2011).

\section{Data Collection}

The major source of data used for this study was the primary sources. A multi-stage random sampling technique was used in the selection of the observations. First, four rubber groups or rubber cooperatives were purposively selected for the study with the total number of 1,316 members. The sample of 300 farmers formed the sample size through Krejcie and Morgan table (1970). Then, a random selection of 300 observations was selected that observations are distributed in time as follows: 136 observations in 2012 and 164 in 2013. The total questionnaires completed in each group or cooperative were 30 households from the Prabatnasing Rubber Fund Cooperative of NongKhai, 106 households from Srithat Farmer Group of UdonThani in 2012, 121 households from the Rubber Fund Cooperative of KhonKaen and 43 households from the Kandong Rubber Fund Cooperative of Buriram (2013). Information was obtained about the socio-economic characteristics of the Para rubber farmers and the levels of their production and output.

\section{Model Specifications}

Aigner et al. (1977) and Meesusen and van Den Broeck (1977) proposed a stochastic frontier production function, which has firm effects assumed to be distributed as a truncated normal random variable. The stochastic production function is defined in Equation (1) and (2) as follows:

$$
\begin{aligned}
& Y_{i}=f\left(x_{i} ; \beta\right)+e_{i} \text { where } i=1,2, \ldots, N \\
& e_{i}=v_{i}-u_{i}
\end{aligned}
$$

where, $Y_{i}$ is production of the $i$ sample farm; $f\left(x_{i} ; \beta\right)$ is a suitable function such as Cobb-Douglas or translog production functions, $x_{i}$ is inputs for the $i$ farm and $a$ vector, $\beta$, of unknown parameters. $e_{i}$ is an error term. Measure of technical efficiency for individual farmer was calculated by the observed output to the corresponding frontier output in Equation (3):

$T E_{i}=\exp \left(-u_{\mathrm{i}}\right) ; i=1$

Battese and Coelli (1995) expressed the inefficiency effects are as an explicit function of a vector of farmspecific variables. The technical inefficiency effects are expressed in Equation (4):

$u_{j}=\delta z_{j}$

where, for farm $j, z$ is a vector of observable explanatory variables and $\delta$ is a vector of unknown parameters. Thus, 
the parameters of the frontier production function are simultaneously estimated with those of an inefficiency model, in which the technical inefficiency effects are specified as a function of other variables. The one-stage simultaneous approach is also implemented in FRONTIER 4.1 and in addition to the basic parameters the program also provides coefficients for the technical inefficiency model. It has been well recognized that technical efficiency in agricultural production is influenced by physical and socio-economic characteristic which include age, sex, education, family size, extension service and farm experience etc. (Battese and Coelli, 1995; Weir and Knight, 2000; Seyoum et al., 1998)

Given our objectives, we applied a Cobb-Douglas production function and the stochastic frontier, as is specified in Equation (5):

$$
\begin{aligned}
\operatorname{Ln} Y= & \beta_{0}+\beta_{1} \ln X_{1}+\beta_{2} \ln X_{2}+ \\
& \beta_{3} \ln X_{3}+\beta_{4} \ln X_{4}+\beta_{5} \ln X_{5}+v_{i}-u_{i}
\end{aligned}
$$

Where:

$\mathrm{Y}=$ Yield of Para rubber (in $\mathrm{kg}$ )

$\mathrm{X}_{1}=$ Cultivated area (ha)

$\mathrm{X}_{2}=$ No. of trees tapped

$\mathrm{X}_{3}=$ Hired labor (in mandays)

$\mathrm{X}_{4}=$ Chemical fertilizer (in Baht)

$\mathrm{X}_{5}=$ Capital (in Baht)

$\mathrm{v}_{\mathrm{i}}=$ Random noise

$\mathrm{u}_{\mathrm{i}}=$ Inefficiency effects

The inefficiency model is defined in Equation (6):

$U_{i}=\delta_{0}+\delta_{1} Z_{1}+\delta_{2} Z_{2}+\delta_{3} Z_{3}+\delta_{4} Z_{4}+\delta_{5} Z_{5}$

Where:

$\mathrm{U}_{\mathrm{i}}=$ Inefficiency effects

$\mathrm{Z}_{1}=$ Age of farmer

$Z_{2}=$ Education level (year)

$Z_{3}=$ Family size (person)

$Z_{4}=$ Gender $(0=$ female and $1=$ male $)$

$Z_{5}=$ Age of plantation (year)

\section{Results of the Study}

\section{Farmer Characteristics}

The summary of statistical variables used for the stochastic production analyses is presented in Table 1. A majority of rubber farmers were male (71.3\%) and the mean family size was 4.67 persons. On average, farmers had a mean age of 46.86 years old and the level of education was rather low as shown by the mean years of schooling, which was 6.58 years. The average output per farmer per annum was $6,135.28 \mathrm{~kg}$.
The farm sizes ranged between 0.32 ha and 32 ha, with an average size of 4.09 ha and an average number of 1,657.41 tapped trees. The average amount of labour needed on the rubber farms per day required five people. Given that rubber plantations have been newly promoted in this area, the results show that the tapped trees have an average age of about 11.43 years. Moreover, on average farmers used 5,124.03 Baht of chemical fertilizers with a capital outlay of $184,236.29$ baht. These factors reveal that the farmers tend to intensively use capital.

\section{Productivity Analysis}

Table 2 indicates that the variance parameters of the stochastic frontier production function (sigma squared and gamma) are significantly different at the $1 \%$ level, respectively. The parameter sigma squared was 0.366 and different from zero $(\mathrm{p}<0.01)$. This means that it is a good fit and shows the correctness of the distributional form. The value of gamma is equal to 0.672 and is statistically significant at the $1 \%$ level, implying that more than half of the residual variation is due to the efficiency effect. All the coefficients of the inputs in the production function are positive and significant at the $1 \%$ level, but only the chemical fertilizer $\left(\mathrm{X}_{4}\right)$ is nonsignificant. This implies that the cultivated areas, the hired labor, the number of tapped trees and the capital have influenced the outputs of rubber farmers and that these variables have increased as the rubber yields increased.

\section{Level and Determinants of Technical Efficiency}

The inefficiency parameters are specified as those relating to farmers' specific socio-economic characteristics. These include age of farmer $\left(Z_{1}\right)$, educational level $\left(Z_{2}\right)$, family size $\left(Z_{3}\right)$, gender $\left(Z_{4}\right)$ and the age of the rubber plantation $\left(Z_{5}\right)$. The coefficient of age variables was significantly positive in relation to the production efficiency, which suggests that the older the farmers are the more experienced and efficient they would be. Similarly, years of schooling showed a significant $(p<0.01)$ negative coefficient, meaning that the level of technical efficiency of the farmers increases with the level of education. On the other hand, the coefficient of family size is estimated as a positive sign, but is not significant. Moreover, the gender of rubber farmers had a negative sign and was statistically significant at $1 \%$. Male farmers were more technically efficient than female farmers. Additionally, the negative coefficient of the age of plantation is statistically significant at the $1 \%$ level, which indicates a positive effect on technical efficiency.

The predicted Technical Efficiency (TE) ranged between 0.106 and 0.905 . The mean technical efficiency was 0.573 , indicating a mean of $57.3 \% \mathrm{TE}$ of Para rubber. This means there's the possibility of increasing rubber production by about $42.7 \%$. 
Poungchompu, S. and S. Chantanop / American Journal of Agricultural and Biological Sciences 2015, 10 (2): 83.90 DOI: 10.3844/ajabssp.2015.83.90

Table 1. Definition of variables and descriptive statistics

\begin{tabular}{|c|c|c|c|}
\hline Variables & Description & Mean & SD \\
\hline \multicolumn{4}{|c|}{ Production function } \\
\hline Y & Yield of Para rubber $(\mathrm{kg})$ & $6,135.28$ & $8,152.43$ \\
\hline $\mathrm{X}_{1}$ & Cultivated area (ha) & 4.09 & 4.32 \\
\hline $\mathrm{X}_{2}$ & No. of trees tapped & $1,657.41$ & $2,013.39$ \\
\hline $\mathrm{X}_{3}$ & Hired labor (in mandays) & 5.06 & 8.06 \\
\hline $\mathrm{X}_{4}$ & Chemical fertilizer (Baht) & $5,124.03$ & $1,735.23$ \\
\hline $\mathrm{X}_{5}$ & Capital (Baht) & $184,236.29$ & $1.55 \mathrm{E}+05$ \\
\hline \multicolumn{4}{|c|}{ Inefficiency model } \\
\hline $\mathrm{Z}_{1}$ & Age of farmers (in years) & 46.86 & 12.2 \\
\hline $\mathrm{Z}_{2}$ & Schooling year (in years) & 6.58 & 3.71 \\
\hline$Z_{3}^{2}$ & Family size & 4.67 & 1.47 \\
\hline \multirow[t]{3}{*}{$\mathrm{Z}_{4}$} & Gender of tapper & & \\
\hline & 0 Female & 28.7 & \\
\hline & 1 Male & 71.3 & \\
\hline $\mathrm{Z}_{5}$ & Age of plantation (year) & 11.43 & 3.52 \\
\hline
\end{tabular}

Table 2. Maximum likelihood estimation of the production frontier for rubber production

\begin{tabular}{|c|c|c|c|}
\hline Variables & Parameter & Coefficient & t-ratio \\
\hline \multicolumn{4}{|l|}{ Production function } \\
\hline Constant & $\mathrm{B}_{0}$ & 0.556 & $3.788^{* * *}$ \\
\hline Cultivated area $\left(\mathrm{X}_{1}\right)$ & $\mathrm{B}_{1}$ & 0.264 & $3.214^{* * *}$ \\
\hline No. of trees tapped $\left(\mathrm{X}_{2}\right)$ & $\mathrm{B}_{2}$ & 0.217 & $3.435^{* * *}$ \\
\hline Hired labor $\left(\mathrm{X}_{3}\right)$ & $\mathrm{B}_{3}$ & 0.159 & $2.828^{* * *}$ \\
\hline Chemical fertilizer $\left(\mathrm{X}_{4}\right)$ & $\mathrm{B}_{4}$ & 0.011 & $0.355^{\mathrm{NS}}$ \\
\hline Capital $\left(\mathrm{X}_{5}\right)$ & $\mathrm{B}_{5}$ & 0.103 & $3.667^{* * *}$ \\
\hline \multicolumn{4}{|l|}{ Inefficiency model } \\
\hline Constant & $\delta_{0}$ & 0.669 & $2.361^{* *}$ \\
\hline Age of farmer $\left(Z_{1}\right)$ & $\delta_{1}$ & -0.315 & $-1.639^{*}$ \\
\hline Education level $\left(\mathrm{Z}_{2}\right)$ & $\delta_{2}$ & -0.453 & $-3.431^{* * *}$ \\
\hline Family size $\left(Z_{3}\right)$ & $\delta_{3}$ & 0.101 & $0.669^{\mathrm{NS}}$ \\
\hline Gender $\left(Z_{4}\right)$ & $\delta_{4}$ & -0.478 & $-3.227^{* * *}$ \\
\hline Age of plantation $\left(Z_{5}\right)$ & $\delta_{5}$ & -0.670 & $-3.313^{* * *}$ \\
\hline \multicolumn{4}{|l|}{ Variance parameter } \\
\hline Likelihood ratio & & -221.438 & \\
\hline $\operatorname{Sigma-square}\left(\delta^{2}\right)$ & & 0.366 & $4.503^{* * *}$ \\
\hline Gamma (r) & & 0.672 & $5.816^{* * *}$ \\
\hline TE mean & & 0.573 & \\
\hline
\end{tabular}

Table 3. Frequency distribution of Technical efficiency among rubber farmer

\begin{tabular}{lcc}
\hline Range of TE & Frequency & Percentage \\
\hline Less than 0.20 & 8 & 2.67 \\
$0.21-0.30$ & 20 & 6.67 \\
$0.31-0.40$ & 39 & 13.00 \\
$0.41-0.50$ & 32 & 10.67 \\
$0.51-0.60$ & 59 & 19.66 \\
$0.61-0.70$ & 54 & 18.00 \\
$0.71-0.80$ & 54 & 18.00 \\
More than 0.80 & 34 & 11.33 \\
\hline
\end{tabular}

The distribution in the technical efficiency of the farmers reveals that approximately $46.7 \%$ of rubber farmers had a TE index below the mean TE while $53.3 \%$ of rubber farmers was above the TE mean. Moreover, the majority $(88.67 \%)$ of the farmers produced rubber with efficiency TE of below 0.80 , while only a few $(11.33 \%)$ of farmers had a TE rating of over 0.80 (Table 3 ).

\section{Discussion and Recommendations}

The findings of the study revealed that all inputs except chemical fertilizer contributed positively to the output of rubber production. It is obvious that the majority of rubber farmers with small holdings used hired labor for tapping and collecting the latex, leading to a higher proportion of total production cost. The rubber tapping activities included the sharpening of the tapping knife, preparing tapping tools, tapping, collecting rubber latex, preparing yields (e.g., latex or rubber sheets) and taking yields to the sales site. Tapping wages are based on a crop sharing contract system between rubber plantation owners and share tappers. The share cropping tapping systems settled between rubber owners and the contract tappers found in the study area 
were 60:40 and were consistent with the study of Chew (1991). That means that the tapper may get $40 \%$ of the Dry Rubber Content (DRC) yield while the owner gets the remaining $60 \%$. Thus, it can be concluded that natural rubber production is labor intensive. However, it is constrained by skilled labor, especially by those who can correctly tap rubber trees and not unintentionally harm the trees. Moreover, the chemical fertilizer costs are not significant, but it leads to less income via rubber production. Thus, the government has promoted the use of chemical fertilizer mixing with bio-fertilizer to help farmers gain a competitive advantage, similar to the finding of Sgroi et al. (2014).

The study revealed that the technical efficiency is less than one, which indicates they were not operating on the efficiency frontier. A $57.3 \% \mathrm{TE}$ mean for rubber farmers implied that farmers were not as efficient at around $42.7 \%$, which is lower than the mean TE of rubber farms in the Vietnamese (Tran et al., 1993), in Nigeria (Giroh and Adebayo, 2009) and in Malaysia (Hashim and Nik, 2011). Moreover, the efficiency factors, which were comprised of age of farmer, education, gender and the age of tapped tree, were found to be the significant factors that have affected the variation in efficiency among the farmers. The estimated coefficient of age of farmers is negative and statistically significant at a $10 \%$ level. This result suggests older farmers are more efficient compared with younger ones associated with the finding of Coelli and Battese (1996). The coefficient for the variable of educational level was estimated to be negatively inefficient. Formal education improves the farmers' understanding of new and advanced farming techniques, which leads to increased productivity. In other words, farmers with four or more years of schooling exhibited higher levels of technical efficiency (Bravo-Ureta and Pinheiro, 1997). This finding is associated with Battese et al. (1996); Coelli and Battese (1996); Romain and Lambert (1995) and Seyoum et al. (1998). Regarding, farmers can receive more knowledge and more techniques through the rubber training from local government. But, with the limited number of training officers, they cannot serve all rubber farmers, especially to give advice to rubber farmers individually. As a result, the Office of Rubber Replanting Aid Fund solves this problem by training "Rubber Teachers" to give basic advice about rubber plantations. This project from the Office of Rubber Replanting Aid is a training program for rubber farmers to become "Rubber Teachers" and has been strict in transferring knowledge in that only one rubber teacher will take care of 100 rubber farmers. The officers of the Office of Rubber Replanting Aid Fund have to train and pass on the skills to the rubber teachers to be more professional so that they can apply those skills to perform their roles (The Office of Rubber Replanting Aid Fund, 2014). Similarly, gender positively affects efficiency in that male farmers are more efficient than female farmers because the activities of rubber production include hard labor and long working hours. This is especially true in field work, which is led by male farmers. The work is done at night or in the early morning of each day before the temperatures rise, so that the latex drips longer before coagulating and sealing the cut. Moreover, male farmers are likely to be wealthier and can more quickly acquire newer and more expensive technology. Male farmers may have easy access to credit considering the fact that they own most of the assets in the household, which could be used as collateral to access credit (Justina et al., 2013). In contrast, women are usually responsible for the food crops destined for immediate consumption by the household. Therefore, women and female farmers do not have equal access to resources and this significantly limits their potential in enhancing productivity (Daman, 1999). The coefficient of age of a tapped tree is positive technical efficiency. The rubber tree may live for a hundred years, but its economic life period is only around 32 years, consisting of 7 years in the immature phase and 25 years in the productive phase (The Office of Rubber Replanting Aid Fund, 2014). In comparison, the economic life span of rubber tree is 25-30 years in Malaysia. A tree normally attains the required girth for tapping in the fifth to seventh year after planting. After a period of 30 years, the decline in latex production makes further tapping of the trees uneconomical, so it is best to plant new trees.

\section{Conclusion}

The finding from this research shows that the production cost, labor cost, is so high and has given rise to less productivity in rubber production. The majority of rubber farmers are not technically efficient and there is a potential to increase their efficiency levels by improving the observed factors that determine their efficiency. Variables such as the age of farmers, the farmers' years of education, gender and the age of the trees, were found to be significant in reducing the inefficiency levels of rubber farmers in the area. The level of education might influence the farmer's ability to use available technology. Thus, the recommendation is that the government should give more education through training about rubber production, including tapping trees, especially family tapping labor and tapping labor employment. Furthermore, more education will impact the farmers' knowledge in order to enhance efficiency. 


\section{Acknowledgement}

Support was provided by KhonKaen University, Thailand Research Fund (RDG5520020 and RDG5450006) for research activities.

\section{Funding Information}

This article was funed from Thailand Research Fund (TRF) (+66 8200 2278) and KhonKaen University (KKU) (+66 202011).

\section{Author's Contributions}

Poungchompu Supaporn: Made contribution to conception of research, acquisition of data, analysis and interpretation of data. Also, she drafted and edited the manuscript.

Chantanop Supawadee: Participated in data collection and analysis. She also helped in data interpretation and manuscript evaluation.

\section{Ethics}

The author confirms that this article has followed the ethical guidelines of the American Journal of Agricultural and Biological Sciences.

\section{References}

Aigner, D., C.K. Lovell and P. Schmidt, 1977. Formulation and estimation of stochastic frontier production function models. J. Econ., 6: 21-37. DOI: 10.1016/0304-4076(77)90052-5

Battese, G.E. and S.J. Malik and M.A. Gill, 1996. An investigation of technical inefficiencies of production of wheat farmers in four districts of Pakistan. J. Agric. Econ., 47: 37-49. DOI: $10.1111 /$ j.1477-9552.1996.tb00670.x

Battese, G.E. and T.J. Coelli, 1995. A model for technical efficiency effects in a stochastic frontier production function for panel data. Empirical Econ., 20: 325-332. DOI: 10.1007/BF01205442

Bravo-Ureta, E.B. and E.A. Pinheiro, 1997. Technical, economic and allocative efficiency in peasant farming: Evidence from the Dominican Republic. Developing Econ., 15: 48-67. DOI: 10.1111/j.1746-1049.1997.tb01186.x

Buriram, 2013. Buriram province.

Chew, T.A., 1991. Share contracts in Malaysian rubber smallholdings. Land Econ., 67: 85-98. DOI: $10.2307 / 3146488$

Coelli, T. and G. Battese, 1996. Identification of factors which influence the technical inefficiency of Indian farmers. Aus. J. Agric. Econ., 40: 103-128. DOI: $10.1111 /$ j.1467-8489.1996.tb00558.x
Daman, P., 1999. Rural women, food security and agricultural cooperatives in rural development and management Centre. Proceedings of the 4th AsianAfrican International Conference on Women in Agricultural Cooperatives in Asia and Africa, Aug. 2429, ICA, AARRO, JA-Zenchu and IDACA, Tokyo.

Giroh, D.Y. and E.F. Adebayo, 2009. Analysis of the technical inefficiency of rubber tapping in rubber research institute of Nigeria, Benin City, Nigeria. J. Hum. Ecology, 27: 171-174.

Grist, P., K. Menz and Thomas, 1998. Modified BEAM rubber agroforestry models: RRYIELD and RRECON. ACIAR Technical Reports Series 42: 43. In The Australian Centre for International Agricultural Research, Australia. ISBN-10: 1-86320-225-0.

Hashim, N. and M. Nik, 2011. Technical efficiency for rubber smallholders under Risda's supervisory system using stochastic frontier analysis. J. Sustainability Sci. Management, 6: 156-168.

Justina, A.O., R. M. Al-Hassan and E. E. Onumah, 2013. Productivity and technical efficiency of cocoa production in eastern Ghana. J. Econ. Sustainable Development, 4: 106-117.

KhonKaen, 2013. KhonKaen province.

Krejcie, R.V. and D.W. Morgan, 1970. Determining sample size for research activities. Educational Psychological Measur., 30: 607-610.

Laura, R., 2006. Rubber plantation performance in Northeast and East of Thailand in relation to environmental conditions. Unpublished dissertation in partial fulfillment of the requirements for the degree of Master of Forestry Ecology, Helsinki University, Finland.

Meesusen, W. and J. van Den Broeck, 1977. Efficiency estimation from Cobb-douglas production functions with composed errors. Int. Econ. Rev., 18: 435-444. DOI: $10.2307 / 2525757$

Nongkhai, 2013. Nongkhai province.

OAE, 2011. Rubber plantation in Northeast.

Rahman, S.M. and J. Takeda, 2007. Measuring the costs of production based on sizes of farm operation: A study on rice farmers in Jessore District of Bangladesh. Am. J. Sci., 4: 274-283. DOI: 10.3844/ajassp.2007.274.283

Romain, R. and R. Lambert, 1995. Efficacite Technique et Couts de Production Dans les SecteursLaitiers du Quebec et de 1=Ontario. Canadian J. Agric. Econ., 43: 37-55. DOI: 10.1111/j.1744-7976.1995.tb00106.x

Seyoum, E.T., G.E. Battese and E.M. Fleming, 1998. Technical efficiency and productivity of maize producers in eastern Ethiopia: A study of farmers within and outside the Sasakawa-Global 2000 project. Agric. Econ., 19: 341-348. DOI: 10.1016/S0169-5150(98)00037-1 
Sgroi, F., A.M. Di Trapani, R. Testa and S. Tudisca, 2014. Strategy to increase the farm competitiveness. Am. J. Agric. Biol. Sci., 9: 394-400.

DOI: 10.3844 /ajabssp.2014.394.400

The Office of Rubber Replanting Aid Fund, 2014. Rubber and rubber teacher.

The Thai Rubber Association, 2013. Rubber situation.

Udonthani, 2013. Udonthani province.

The Thailand Life, 2015. Map of Isaan. The Northeast Thailand.
Tran, V.H.S., T.J. Coelli and F. Euan, 1993. Analysis of the technical efficiency of state rubber farms in Vietnam. J. Agric. Econ., 9: 183-201. DOI: 10.1016/0169-5150(93)90047-G

Weir, S. and J. Knight, 2000. Education externalities in rural Ethiopia: Evidence from average and stochastic Frontier production function. Working Paper CSAE WPS/2000-4. Centre for the Study of African Economies, University of Oxford, UK. 